\title{
Sources and Short Bibliography
}

The Huxley Papers, The College Archives, Imperial College London.

Huxley ALS collection, The Royal College of Physicians of London.

Alter, Peter, The reluctant patron: science and the state in Great Britain, 1850-1920, transl. Angela Davies, Leamington Spa, Berg, 1986.

Barr, Alan P. (ed.), Thomas Henry Huxley's place in science and letters, Athens, GA, University of Georgia Press, 1997.

Bibby, Cyril, T. H. Huxley: scientist, humanist, and educator, London, Watts, 1959.

- Scientist extraordinary: the life and scientific works of Thomas Henry Huxley, 1825-1895, Oxford and New York, Pergamon Press, [1972].

Clodd, Edward, Thomas Henry Huxley, Edinburgh, William Blackwood and Sons, 1902.

Corfield, Richard, The silent landscape: in the wake of HMS Challenger, 1872-1876, London, John Murray, 2004.

Dawson, Warren R., The Huxley papers: a descriptive catalogue of the correspondence, manuscripts and miscellaneous papers of the Rt. Hon. Thomas Henry Huxley, London, published for the Imperial College of Science and Technology by Macmillan, 1946.

Deacon, Margaret, Scientists and the sea, 1650-1900, 2nd ed., Aldershot, Ashgate, 1997.

Desmond, Adrian, Huxley: from devil's disciple to evolution's high priest, London, Penguin, 1997; originally published in 2 vols: Huxley, the devil's disciple, London, Michael Joseph, 1994; Huxley: evolution's high priest, London, Michael Joseph, 1997. Pages are cited from the Penguin edition.

'Huxley, Thomas Henry (1825-1895)', in H. C. G. Matthew and Brian Harrison (eds), Oxford dictionary of national biography, Oxford and New York, Oxford University Press, 2004, vol. 29, pp. 99-111; http://www.oxforddnb.com

di Gregorio, Mario A., T. H. Huxley's place in natural science, New Haven, Yale University Press, 1984.

Eve, A. S., and Creasey, C. H., Life and work of John Tyndall, London, Macmillan, 1945.

Foster, Michael, and Lankester, E. Ray (eds), The scientific memoirs of Thomas Henry Huxley, London, Macmillan; and New York, D. Appleton, 1898-1902, 4 vols.

Geison, Gerald L., Michael Foster and the Cambridge School of Physiology: the scientific enterprise in late Victorian society, Princeton, Princeton University Press, 1978.

Hall, Marie Boas, All scientists now: the Royal Society in the nineteenth century, Cambridge and New York, Cambridge University Press, 1984.

Heuss, Theodor, Anton Dohrn: a life for science, translated from the German by Liselotte Dieckmann, Berlin and New York, Springer, 1991.

Huxley, Aldous, T.H. Huxley as a man of letters, London, Macmillan, 1932.

Huxley, Leonard, Life and letters of Thomas Henry Huxley, 2 vols, London, Macmillan, 1900. Pages are cited from this two-volume English edition. 


\section{Short Bibliography}

Huxley, Thomas H., Collected essays, 9 vols, London, Macmillan, 1893-1894.

Irvine, William, Apes, angels, and Victorians: a joint biography of Darwin and Huxley, London, Weidenfeld and Nicolson, 1955.

Jensen, J. Vernon, Thomas Henry Huxley: communicating for science, Newark, University of Delaware Press; London, Associated University Presses, 1991.

Leighton, Gerald, T. H. Huxley, his life and work, London, T C \& E C Jack; New York, Dodge publishing, [pref. 1912].

Lester, Joseph, E Ray Lankester and the making of modern British biology, Peter J. Bowler (ed.), Faringdon, Oxon, British Society for the History of Science, 1995.

Lyons, Sherrie L., Thomas Henry Huxley: the evolution of a scientist, Amherst, NY, Prometheus Books, 1999.

Matthew, H. C. G., and Harrison, Brian (eds), Oxford dictionary of national biography, Oxford and New York, Oxford University Press, 2004, 61 vols; http://www. oxforddnb.com

Mitchell, P. Chalmers, Thomas Henry Huxley: a sketch of his life and work, London, Methuen, 1913.

Paradis, James G., T. H. Huxley: man's place in nature, [Lincoln], University of Nebraska Press, 1978.

Romano, Terrie M., 'Foster, Sir Michael (1836-1907)', in H. C. G. Matthew and Brian Harrison (eds), Oxford dictionary of national biography, Oxford and New York, Oxford University Press, 2004, vol. 20, pp. 520-523; http://www.oxforddnb.com

White, Paul, Thomas Huxley: making the "man of science", Cambridge, Cambridge University Press, 2003. 